\title{
Instructional Communication: A Course Design Case
}

\section{Brian Rugen \\ Meiji University}

\section{Reference Data:}

Rugen, B. (2019). Instructional communication: A course design case. In P. Clements, A. Krause, \& P. Bennett (Eds.), Diversity and inclusion. Tokyo: JALT.

Instructional communication is a field of study about the communication strategies for effective classroom teaching. This paper is a report on the development of an instructional communication graduate course at a private university in Tokyo. First the importance and need for the course is discussed, the author arguing that general pedagogical communication skills have been somewhat neglected in second language teacher training programs. Then the development of the course is discussed in terms of the following course design considerations: goals and objectives, content, organization, and assessment. It is hoped that the paper will provide insights that individual teachers can use when developing and planning their own courses in second language teacher education programs in Japan.

教育的コミユニケーションは、効果的な教育のためのコミュニケーション戦略を検討する研究分野である。本論文では、東 京の私立大学の大学院における教育的コミユニケーションの授業の開発について報告する。まず、当該授業の動機と必要性 について論じ、一般的な教育的コミュニケーションスキルは英語教員養成プログラムにおいて軽視されてきたと説くそしして、 当該授業の開発について、授業デザインにおいて考慮すべき事項(目標、内容、構成、および評価方法)の観点から論じる。本 論文が、日本の英語教員養成において、単なる英語の習熟度を超えて、教室におけるコミユニケーションスキルの重要性に関 する対話を開くことを期待したい。

nstructional communication is an interdisciplinary field of study combining insights from the areas of pedagogy, communication, and educational psychology in order to examine the communication behaviors-both verbal and nonverbal-used by both teachers and students in the process of teaching and learning (Mottet, Richmond, \& McCroskey, 2006; Powell \& Powell, 2015; White, 2016). The field of instructional communication concerns the question of how teachers can communicate in ways that help their students learn.

In this paper, I describe the development of an instructional communication course for a graduate program in English Language Education at a private university in Tokyo. First I describe the impetus for the course. Then I highlight how key curricular design principles informed the course's development.

\section{Impetus and Need for the Course}

I first started thinking about the importance of instructional communication while teaching in a graduate TESOL program in the U.S.A. Many of the students in the program were international students-either preservice teachers of English or in-service teachers early in their career taking a leave of absence to pursue a graduate degree. In informal discussions with students, many, including the Japanese students, expressed concerns about their level of English language proficiency. In particular, a concern with English pronunciation seemed to be at the top of the list. This, in turn, affected their own confidence as well as their developing identities as English language teachers.

At the same time, however, the students' microteaching demonstration lessons that they occasionally delivered in class told a different story. Rarely, if ever, did I feel that pronunciation was an issue that affected the success of a particular demonstration lesson. Instead, what I frequently noticed was the student teacher fixed and frozen behind a table or podium at the front of the class during the entire demonstration lesson. Whenever an activity transitioned from a teacher-centered explanation to a studentcentered activity, the student teachers often used the time to review lesson plans and sometimes even scripts of what they had prepared to say next. There seemed to be an imaginary line between the student teachers and students.

Much has been written on what the knowledge base for teacher education, including second language teacher education (SLTE), should include. Communication skills is 
one important domain included in many models of that knowledge base. In Richards's (1998) model, for example, he highlighted two dimensions of communication skills: (a) general communication skills, such as voice, personality, and rapport and (b) general proficiency levels in the target language being taught. In the literature for nonnative English speaking teachers, this second dimension is by far the one that is most often addressed. Suggestions in the literature often focus on the need for more training in areas such as grammar, pronunciation, and vocabulary (Cullen, 1994; Lee, 2004; Lin, Wang, Akamatsu, \& Riazi, 2005). These are certainly important suggestions; however, I began to wonder whether addressing additional communication behaviors-Richards's first dimension-would be helpful for students. As a result, in my final years of working in the U.S.A., I began training students in strategies for teacher immediacy-just one aspect of instructional communication. The short training exercises were integrated into an existing course in the MA TESOL curriculum (Rugen, 2018). The exercises seemed helpful, in that video evidence showed students making strides in erasing that imaginary line mentioned above.

In my current context in Japan, I wanted to build on this previous work by developing a course dedicated solely to instructional communication. In addition to introducing major components, theories, and strategies of instructional communication, the course would also need to provide students with opportunities to practice the strategies. In fact after informal discussions with several faculty members and students from the English Language Education graduate program, I learned there was a need for microteaching opportunities in the curriculum.

In the end, then, I wanted to develop a course that would (a) introduce the theory and practice of instructional communication to students, and (b) offer opportunities to practice and reflect on the communication behaviors and strategies learned in class. The following discussion about particular aspects of curriculum design show how this was done.

\section{The Course}

The course design process consists of several overlapping components. Having briefly addressed needs above, I will first introduce some contextual information before focusing on the following four components of course design, adapted from two well-known texts on language curriculum design (Nation \& Macalister, 2009; Graves, 2000): formulating goals and objectives, conceptualizing content, organizing the course, and assessment.

The course meets for 100 minutes, 14 times per semester. Graduate students in the course are diverse; some teach English at the elementary school level, some at the high school level, and some at the university level. Other students may be teaching at private jukus and others may have little to no experience teaching English at all. Students in the class are either pursuing a graduate degree only (having a teaching license already) or pursuing a teaching license and graduate degree concurrently.

\section{Formulating Goals and Objectives}

Goals and objectives are different, and well-developed curricula and language courses will have both stated goals and objectives. Goals are general statements and future oriented. Objectives are statements about how a goal is achieved. They are more specific than goals and represent the steps that build toward reaching the goal. Together, goals and objectives help build a clear vision of what should be taught in a course.

For example, one might have a goal of running a full marathon by the end of a particular calendar year. That goal is general (but not vague) and future oriented. In order to achieve that goal, one would have several, more specific objectives, such as running 30 kilometers per week, getting eight hours of sleep per night, and/or drinking two additional glasses of water per day.

For this course in instructional communication, the following four goals were developed:

1. Students will understand the origins and theoretical development of the field of instructional communication.

2. Students will learn how select principles of instructional communicationcredibility, clarity, immediacy, power and authority, motivation and engagement, anxiety, and affinity-seeking strategies-are connected to teaching and learning.

3. Students will review key principles in effective lesson design.

4. Students will demonstrate key instructional communication behaviors and strategies through a series of video-mediated microteaching demonstration lessons.

In order to meet these goals, the following specific objectives were established. As Graves (2000) noted, it is possible for some objectives to serve more than one goal (p. 78). Thus, after each of the following objectives, the goal(s) it serves is stated in parenthesis:

1. Students will complete weekly study guides based on the readings and participate in interteach sessions with a different partner every week (G1, G2).

2. Students will demonstrate understanding of goals/objectives; types of classroom activities; variety, sequencing, and pacing; and materials design through in-class hands-on tasks (G3). 
3. In the first half of the semester, students will deliver one 15-20 minute videomediated microteaching demonstration lesson based on a published activity (G4).

4. In the second half of the semester, students will deliver one 20-25 minute videomediated microteaching demonstration lesson based on an original activity (G4).

5. In written self-reflections following demonstration lessons, students will connect specific strategies and behaviors that they used to principles of credibility, clarity, immediacy, power and authority, motivation and engagement, anxiety, and affinityseeking strategies (G2).

6. In whole class discussions following demonstration lessons, students identify strategies and behaviors that their classmates used, connecting them to principles of instructional communication (G2).

\section{Conceptualizing Content}

As mentioned above, Richards's (1998) model regarding the knowledge base of SLTE is a useful one. He suggested the following six domains of knowledge, or content, as necessary in SLTE: (a) theories of teaching, (b) teaching skills, (c) communication skills, (d) subject matter knowledge, (e) pedagogical reasoning skills, and (f) contextual knowledge. The content for this instructional communication course covers two of these domains: the domain of communication skills and the domain of teaching skills.

Related to the domain of communication skills, content in the course includes background information on the historical development of instructional communication as well as the multidisciplinary nature of the field. Students are then introduced to the most important principles of instructional communication, including clarity, immediacy, credibility, power and authority, motivation and engagement, anxiety, and affinityseeking strategies.

When discussing these principles, we identify specific behaviors and techniques that teachers can use in the classroom. For example, after reviewing the literature on the importance of the teacher clarity principle and its connections to student learning, we discuss specific techniques associated with clarity, including teaching in a step-by-step manner, using an appropriate pace, informing students of lesson objectives, repeating oneself when necessary, providing relevant examples, and using various questioning techniques.

Students also evaluate their own perceived strengths and weaknesses with these principles of instructional communication before viewing example teaching videos about which we discuss the presence, or absence, of the principles. Video clips of language teaching can be found either online at sites such as YouTube or on DVDs that are sometimes packaged together with language teaching methodology textbooks (e.g., Harmer, 2015).

A second strand of content, related to what Richards (1998) called the domain of teaching skills, includes concepts related to lesson design and the actual delivery of two video-mediated microteaching demonstration lessons. Video-mediated microteaching is simply the process of video recording teachers' microteaching lessons and spending time talking about the lessons together in a subsequent class. The microteaching lessons are delivered and video recorded,in class, with the other students in the class assuming the roles of language learners. These microteaching lessons help students develop a heightened awareness of the application of instructional communication behaviors in their actual teaching.

In the first microteaching demonstration lesson, students are provided with a lesson plan for a 15-20 minute activity that they deliver to the class. Some of the best resources for this include the Cambridge Handbooks for Language Teachers series and the Oxford Resource Books for Teachers series. The activities from these books offer easy-to-follow, consistent lesson plan templates. This frees students, in the first microteaching lesson, from pressure associated with designing a short activity. It also relieves them from any responsibility associated with the activity's content. Instead, they can focus solely on their instructional communication. As such, students choose two to three instructional communication behaviors or strategies to focus on when delivering the microteaching lesson.

In the second microteaching demonstration lesson, students are required to design their own 20-25 minute activity, based on principles of effective lesson design. Then, they deliver this lesson to the class. The aspects of lesson design that we cover in the second half of the course include the following:

1. Goals and objectives: Students learn the difference between the two and practice, in class, writing specific, measurable objectives for individual classroom lessons.

2. Types of classroom activities: Students review a continuum of in-class techniques, ranging from controlled to semicontrolled to free (i.e., Brown, 2007, pp. 184-187). We discuss their suitability in relation to an individual lesson's objective(s).

3. Variety, sequencing, and pacing: Building on the previous aspect, students learn about the importance of the organization-variety, sequencing, and pacing-of the activities. 
4. Learning materials design: Finally, students are introduced to some basic principles of materials design that they need to consider for any materials they use in their final microteaching demonstration lesson (or for future materials as well). Tomlinson (2011) provides a useful summary of 16 important principles for effective materials design that students use as a guide in the design of their own materials.

\section{Organizing the Course}

The first half of the course targets the first content component-the theories and principles of instructional communication. To structure this learning, students are given assigned readings and a study guide to complete each week. In class, students participate in what are called interteach sessions. Interteaching is a pedagogical strategy for university-level instruction that departs from this standard lecture format.

An interteach session is a structured, mutually informing conversation between two people, lasting 30 to 40 minutes, focused on a reading assignment and study guide (5-10 questions) that are to be completed prior to the day of the interteach. The study guide questions are written by the professor in order to assist the students' reading comprehension and to provide direction for the interteach. In class students are paired with a partner (rotating so as to not work with the same person twice) with whom they will discuss the reading. At the end of each interteach session, the professor can lead a whole-class discussion based on whatever questions came up during the interteach sessions. In other words, students determine the topic of the whole-class discussion with their own questions and/or comments. Every 2 weeks, there are short quizzes with a few questions from the study guides. The questions are exactly the same as they appeared on the study guides. The students are motivated, then, to read in advance and participate actively in the interteach session in order to perform well on the biweekly quizzes.

In Week 7, students deliver their first microteaching demonstration lesson. The lessons are video recorded and posted online to our course site. Students review the recordings outside of class and in Week 8 we discuss the recordings in class.

Weeks 9 to 12 of the course cover the particular aspects of lesson design mentioned in the previous section. Instead of using the interteach strategy, however, a mini-lecture focused on the reading's main points is delivered, followed by a hands-on activity for the students to complete. For example, after a mini-lecture on writing goals and objectives for course and lesson planning, students are given a list of several types of English courses. They then need to practice writing one goal for the course and one or two objectives to meet that goal. After that, I provide a checklist of criteria for a strong objective. Students then use the checklist to first revise their list of objectives from the previous task and then to analyze a new list of objectives given to them, choosing the ones that meet and do not meet the criteria.

The final 2 weeks of the course are devoted to the final microteaching demonstration lesson, where it is hoped students will be able to refine their instructional communication strategies while delivering the original lesson they designed. The purpose of each microteaching demonstration lesson is to practice various instructional communication strategies. However, with the first lesson, students have fewer responsibilities in the preparation. The second lesson places more responsibility on the students while at the same time requiring an improved level of proficiency in instructional communication. Therefore, there is level of scaffolding built into the course, in that the second microteaching lesson requires greater independence than the first microteaching lesson.

\section{Assessment}

Nation and Macalister (2009) identified six different types of assessment in language curriculum design: placement assessment, observation of learning, short-term achievement assessment, diagnostic assessment, achievement assessment, and proficiency assessment. The assessment plan in this instructional communication course incorporated three of them: observation of learning, short-term achievement assessment, and achievement assessment. First, the biweekly quizzes - an important component of the interteach strategy-served as an example of short-term achievement assessments throughout the course. Such assessments serve a twofold purpose: (a) they provide the instructor with feedback regarding students' progress and (b) they have motivational purposes, as students will want to keep up with readings and study guides in order to achieve feelings of success on the quizzes. A second major type of assessment was observation of learning. This is a type of formative assessment that focuses more on the in-class tasks that students complete in order to establish whether the task encourages student learning or the extent to which, if any, the task needs to be modified (Nation \& Macalister, 2009, p. 111). For example, in the second half of the course, careful attention was paid to the in-class activities designed to help students understand the aspects of lesson design. A third type of assessment was the achievement assessments. The two microteaching demonstration lessons were an example of this. The demonstration lesson assessment includes both a numerical score based on a rubric and a student self-reflection, after having watched the recording of their teaching. Both written (from the instructor, on the rubric) and oral (from classmates, in the whole-class discussion) feedback is included in this assessment. 


\section{Conclusion}

In this paper I have discussed the development of a graduate course in instructional communication. The graduate course targets some of the most important and relevant principles and strategies from the field of instructional communication and allows the Japanese teachers of English time to practice them in class. In addition, the review of key lesson planning principles in the second half of the course helps the students in their preparation of the microteaching lessons through which the instructional communication strategies can be practiced.

The process of course design is not a linear one. It is a cyclical process, with revisions occurring on an ongoing basis. Throughout the course, students discussed their perceived strengths and weaknesses in various aspects of instructional communication. Then, after watching themselves practice these techniques on video, further reflections took place both in writing and in whole class discussions. Clearly, the idea of reflection was important in the course; however, its importance was never explicitly addressed, as it has been in the literature on SLTE (Farrell, 2015). As a result, one revision I would like to address in the future is to help students see reflection as a series of phases, which Stanley (1998) described as the move from "engaging with reflection" to "practicing reflection," in the context of learning how to improve one's instructional communication.

Finally, practicing effective communication skills will not only benefit the teacherstudent interactions in the language classroom but also the interactions that extend beyond the classroom, as teachers are often required to communicate with other teachers, administrators, staff, and even parents. As well-known musical composer John Powel once noted, "Communication works for those who work at it" (as cited in Madhukar, 2017). Thus, in addition to the importance of continually working toward higher levels of proficiency in a target language, it is equally important for teachers to work toward improving their general pedagogical communication skills in the classroom as well.

\section{Bio Data}

Brian Rugen is an associate professor in the School of Global Japanese Studies at Meiji University. His teaching and research interests include discourse and identity; curriculum/materials development in TESOL; language teacher training; and sport, culture, and narrative representations. In his spare time, he enjoys long-distance running.

\section{References}

Brown, H. D. (2007). Teaching by principles: An interactive approach to language pedagogy (3rd ed.). White Plains, NY: Pearson.

Cullen, R. (1994). Incorporating a language improvement component in teacher training programmes. ELT Journal, 84(2), 162-72. https://doi.org/10.1093/elt/48.2.162

Farrell, T. S. C. (2015). Promoting teacher reflection in second language education: A framework for TESOL professionals. New York, NY: Routledge.

Graves, K. (2000). Designing language courses: A guide for teachers. Boston, MA: Heinle \& Heinle. Harmer, J. (2015). The practice of English language teaching (5th ed.). Essex, England: Pearson.

Lee, I. (2004). Preparing nonnative English speakers for EFL teaching in Hong Kong. In L. KamhiStein (Ed.), Learning and teaching from experience: Perspectives on nonnative English-speaking professionals (pp. 230-250). Ann Arbor: University of Michigan Press.

Lin, A., Wang, W., Akamatsu, N., \& Riazi, M. (2005). International TESOL professionals and teaching English for glocalized communication. In S. Canagarajah (Ed.), Reclaiming the local in language policy and practice (pp. 197-224). Mahwah, NJ: Erlbaum.

Madhukar, R. K. (2017). Business Communication (3rd ed.). New Delhi, India: Vikas.

Mottet, T. P., Richmond, V. P., \& McCroskey, J. C. (Eds.). (2006). Handbook of instructional communication. New York, NY: Routledge.

Nation, I. S., \& Macalister, J. (2009). Language curriculum design. New York, NY: Routledge.

Powell, R. G., \& Powell, D. L. (2015). Classroom communication and diversity. New York, NY: Routledge.

Richards, J. C. (1998). Beyond training: Perspectives on language teacher education. New York, NY: Cambridge University Press.

Rugen, B. (2018). Developing teacher immediacy in language teacher education. The Language Teacher, 42(2), 13-17. Retrieved from https://jalt-publications.org/sites/default/files/pdfarticle/42.2tlt-art3.pdf

Stanley, C. (1998). A framework for teacher reflectivity. TESOL Quarterly, 32(3), 584-591. https://doi.org/10.2307/3588129

Tomlinson, B. (2011). Introduction: principles and procedures of materials development. In B. Tomlinson (Ed.), Materials development in language teaching (2nd ed., pp. 1-31). Cambridge, England: Cambridge University Press.

White, K. (2016). Teacher communication: A guide to relational, organizational, and classroom communication. London, England: Rowman \& Littlefield. 